\title{
DO MODELO AGRÁRIO-EXPORTADOR AO CAPITALISMO URBANO- INDUSTRIAL: AS POLÍTICAS DE FORMAÇÃO DA FORÇA DE TRABALHO NO ÂMBITO DA EDUCAÇÃO ESCOLAR NO BRASIL ENTRE 1930 E 1945
}

\author{
Prof. Dr. Paulo César de Souza Ignácio \\ IF Sudeste MG - Campus Juiz de Fora \\ paulo.ignacio@ifsudestemg.edu.br
}

\section{RESUMO:}

O presente texto se constitui no resultado parcial de um projeto de pesquisa o qual partiu do entendimento de que a relação entre o desenvolvimento das forças produtivas e as políticas públicas que norteiam os processos de formação da força de trabalho - assim como a realidade em sua totalidade - é mediada pelas relações sociais e produtivas, historicamente construídas pelos homens em suas relações com os outros homens e com a natureza através do trabalho. Com ele, buscamos apreender e expor o significado histórico das reformas educacionais - especificamente das reformas Francisco Campos e Capanema - realizadas entre os anos de 1930 e 1945, período no qual o país transitou do modelo agrário-exportador para o modelo urbano-industrial, verificando o que elas representaram em termos de disciplinamento da formação da força de trabalho para atender o processo de industrialização, assim como o que representaram em termos da consolidação de estruturas de ensino diferenciadas, desarticuladas e não equivalentes, sobre a qual se desenvolveu o conceito de dualidade estrutural na organização da educação escolar no Brasil.

Palavras-Chave: desenvolvimento das forças produtivas; formação da força de trabalho; reformas educacionais.

\section{OF AGRARIAN-EXPORTER MODEL TO URBAN-INDUSTRIAL CAPITALISM: POLICIES FOR TRAINING OF WORKFORCE UNDER THE SCHOOL EDUCATION IN BRAZIL BETWEEN 1930 AND 1945}

\begin{abstract}
:
This text constitutes the partial results of a research project which starts from the understanding that the relationship between the development of productive forces and public policies that guide the formation processes of the work force - as well as reality in its totality - is mediated by social relations and productive, historically constructed by men in their relationships with others and with nature through work. With it, we understand and explain the historical significance of the educational reforms - especially reforms Francisco Campos and Capanema - between the years 1930 and 1945, during which the country passed from agro-exporting model for urban-industrial model, verifying what they represented in terms of disciplinary training of the workforce to meet the industrialization process, like that represented in terms of consolidation of structures of differentiated teaching, disjointed and not equivalent, of which it developed the concept of duality structural organization of schooling in Brazil.

Keywords: development of productive forces; training of the workforce; educational reforms.
\end{abstract}




\section{Introdução}

As mudanças na base técnica da produção, introduzidas pela absorção cada vez maior da ciência e de novas tecnologias aliada às novas formas de gestão e organização do trabalho - processo já amplamente conhecido como reestruturação produtiva -, sempre provocaram reflexos contundentes nas políticas de formação da força de trabalho.

$\mathrm{Na}$ história mais recente do Brasil, esses reflexos se traduziram, por exemplo, no tratamento dado à educação na Constituição de 1988. Sua promulgação abriu espaço para mudanças em todo o arcabouço jurídico do país, o que especificamente no campo da educação, se concretizou com a nova LDB - Lei n 9.394 - em 20 de Dezembro de 1996. Esta por sua vez, deu oportunidade ao Estado de executar reformas específicas à educação profissional e tecnológica, que vão desde o Projeto de Lei $\mathrm{n}^{\circ} 1.603$, que deu entrada na Câmara dos Deputados em março de 1996, antes mesmo à promulgação da nova LDB, passando pelo Decreto n 2.208 de 17 de abril de 1997, pelo Decreto ${ }^{\circ} 5.154$ de 23 de julho de 2004 e, finalmente, pela reforma dos artigos e capítulo que tratam da educação profissional e tecnológica na LDB, instituída pela Lei nº 11.741 de 16 de julho de 2008.

No entanto, essa relação entre o desenvolvimento das forças produtivas e os processos de formação da força de trabalho nunca foi privilégio da história recente do Brasil. Se nos reportarmos ao período histórico objeto desse texto, veremos que a transição do modelo produtivo baseado no setor agro-exportador para o modelo urbano-industrial também provocou ajustes significativos no âmbito das políticas públicas voltadas à formação da força de trabalho do país. Dentre estes ajustes, é importante destacar as chamadas reformas Capanema, levadas a efeito na década de 1940 - no auge da vigência do Estado Novo (SAVIANI, 1998b, p. 57-8) -, a fim de demonstrar o que elas significaram

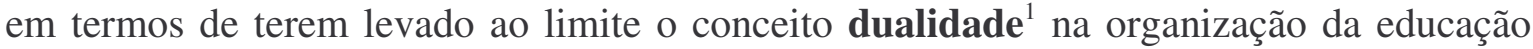
escolar no Brasil.

Do ponto de vista metodológico, partimos da compreensão de que a relação trabalho-educação - assim como a realidade em sua totalidade - é mediada pelas relações sociais e produtivas, historicamente construídas pelos homens em suas relações com os outros homens e com a natureza através do trabalho ${ }^{2}$. Tal opção se apóia na necessidade de tentar apreender a historicidade do desenvolvimento das relações sociais de produção capitalistas, a importância do Estado $^{3}$ em suas definições e como e porque a elas se articularam as políticas de formação da força de trabalho e a adoção de um determinado modelo de desenvolvimento feita pelo bloco no poder.

Assim, após fazermos um breve detóur pela Primeira República com o intuito de assinalar os marcos que contextualizaram a ruptura decorrente do golpe de 1930, o qual mudou o rumo do avanço da acumulação capitalista no país - além de redefinir o papel do Estado na área econômica na direção nacionalista e intervencionista, com vistas a consolidar o pólo urbano-industrial como o eixo dinâmico da economia - analisaremos o que essa ruptura representou em termos de novas exigências educacionais, respondidas com as reformas Francisco Campos em 1931/2 e Capanema em 1942/6 - que criou o SENAI, SENAC e as escolas técnicas - buscando disciplinar a formação da força de trabalho industrial, ação tida como necessária para a aceleração do processo de industrialização. 


\title{
A Primeira República e a Dualidade Estrutural: um breve détour
}

A formação da força de trabalho no âmbito da educação escolar brasileira tem como marco inaugural a criação das Escolas de Aprendizes e Artífices no início do século $\mathrm{XX}^{4}$, muito embora reconheçamos que estas tenham estado muito mais ligadas à formação pré-industrial ou artesanal, além de terem tido um objetivo muito mais social do que técnico. Ao não se articularem com os demais graus de ensino e terem, portanto, um caráter estritamente terminal - pois eram claramente destinadas à recém formada classe operária brasileira, em consequência da (ainda incipiente) industrialização, do crescimento do setor terciário e da própria urbanização - sua criação traz em si por um lado, a formalização da dualidade na estrutura, organização, fins e objetivos da educação escolar brasileira, ao mesmo tempo em que assinala, em termos educacionais, o início do período de transição do modelo capitalista agrário-exportador para o modelo capitalista industrial, como podemos identificar no próprio decreto de criação:

\begin{abstract}
"Considerando: que o aumento constante da população das cidades exige que se facilite às classes proletárias os meios de vencer as dificuldades sempre crescentes da luta pela existência; que para isso se torna necessário, não só habilitar os filhos dos desfavorecidos da fortuna com o indispensável preparo técnico e intelectual, como fazê-los adquirir hábitos de trabalho profícuo, que os afastará da ociosidade, escola do vício e do crime; que é um dos primeiros deveres do Govêrno da República formar cidadãos úteis à Nação." (Decreto Lei nº 7.566 de 23 de Setembro de 1909, apud FONSECA, 1986)
\end{abstract}

No que diz respeito à dualidade, cabe-nos mostrá-la como um reflexo da própria organização da produção nacional e da sociedade brasileira na Primeira República. A despeito de ter pretendido democratizar e universalizar o ensino primário, o sistema criado (escolas normais e grupos escolares) foi insuficiente e insensível ao mundo do trabalho. Por isso, NOSELLA (1998, p.167) qualifica o alcance desse objetivo como "mutilado". O sistema escolar criado foi a expressão humana e política da dualidade da organização social e produtiva. A atividade humana extrativista executada por uma mão-de-obra desqualificada, puramente braçal, "escrava", da qual era exigida um mínimo de criatividade e inteligência, que atravessou os "ciclos" do ouro, da borracha, do café, do gado, da cana-de-açúcar etc. e as formas produtivas industriais modernas, das quais era exigida uma pesada carga de inteligência e de criatividade, somente obtida nas "boas escolas", destinada aos "homens-de-cidade" eram a mais pura expressão dessa dualidade da organização produtiva e social.

Aos muitos trabalhadores que deveriam executar as atividades extrativistas e que, portanto, deveriam apenas adquirir alguns hábitos e noções longe mesmo dos bancos escolares, foi oferecido um tipo de educação: a não-escolar. Para o outro grupo social (minoria) se criou a moderna instituição escolar, que os ensinaria a serem cidadãos e neles inculcaria o "espírito industrialista", de forma que a eles, fosse possível a tarefa de construir as indústrias e os serviços urbanos, bem como inventar as "novas mercadorias".

A proclamação da República brasileira, apesar de ter se inspirado no iluminismo industrial, não representou uma ruptura definitiva com o Ancien Régime (o Império). Na verdade, foi apenas para "francês ver": Não é sem razão que os mesmos personagens do Império entraram no "barco republicano", permanecendo aliás na sua direção. (NOSELLA, op. cit., p.169) 
Prova disso, é que apesar da política educacional da Primeira República ter como objetivo proclamado a alfabetização dos ex-escravos, filhos de imigrantes, camponeses etc. (a grande massa), levando à criação da Escola Normal ${ }^{5}$ - instituição que alimentaria técnica e culturalmente os grupos escolares, incumbidos daquela tarefa -, a influência permitida que as congregações religiosas (sobretudo as femininas francesas) tiveram acabou levando a cabo, concretamente, um ensino altamente elitista, a despeito do rigor e seriedade que essa influência imprimiu às Escolas Normais e aos Grupos Escolares. As "moças de bem", filhas dos grandes fazendeiros, negociantes, altos funcionários, em suma, da elite social recebiam nessas escolas, um ensino, apesar de muito sério e rigoroso, fortemente vincado por uma cultura absolutamente rompida com o mundo do trabalho e impregnada de uma cultura socialmente distintiva.

Os determinantes econômicos desse estado de coisas vão ser encontrados na organização da produção, de caráter quase que exclusivamente agrário-exportador, que tinha nos grupos oligárquicos cafeicultores (principalmente) e cacaueiros sua expressão política. A hegemonia desses grupos de orientação claramente liberais, obviamente se refletiu na organização da educação (escolar), talvez o único dos direitos sociais insinuado na Constituição de 1891, que consagrou na letra da lei, o liberalismo e o "Estado mínimo". (CURY, 1996, p.79).

Nesse período, pode-se afirmar sem sombra de dúvidas, que apesar da educação escolar não ter sido totalmente ignorada no debate político, o viés individualista, "associado a uma forte defesa do federalismo e da autonomia dos Estados, fez com que a educação compartilhasse, junto com outros temas de direitos sociais, os efeitos de um liberalismo excludente e pouco democrático". (CURY, op.cit., p.80)

Assim, a educação não se tornava obrigatória, ancorada que ficou na dimensão do esforço próprio de cada um em vista de demandas individuais. Também a gratuidade fica a cargo dos Estados, apesar de muita discussão sobre se a União poderia intervir ou não nessa matéria, com vistas a uma escolarização básica a toda a população; discussão essa que perpassará toda a Velha República tendo presença forte na Revisão Constitucional de 1926.

Esse breve detóur pela Primeira República permite deixar assinalado os marcos que contextualizaram, no início do século XX, a ruptura que acontece com o golpe de 1930 e que deu um novo rumo "ao avanço da acumulação capitalista no país, no sentido da implantação de um núcleo básico de indústrias de bens de produção, bem como no da redefinição do papel do Estado em matéria econômica, visando tornar o pólo urbanoindustrial o eixo dinâmico da economia." (MENDONÇA, 1988, p.13)

\section{Desenvolvimentismo e Formação da Força de Trabalho no Brasil (de 1930 a 1945)}

Com efeito, os sistemas político e econômico brasileiro, nas décadas anteriores à de 1930, já davam sinais de esgotamento. As crises do modelo agrário-exportador baseado no café, cujos custos eram repassados a toda a sociedade brasileira, enquanto seus benefícios atingiam somente um grupo, já eram sinais de problemas estruturais e conjunturais típicos de uma economia agrário-exportadora (IANNI, 1996, p.27-8), que foram condicionantes da crise de hegemonia do grupo cafeeiro paulista.

\footnotetext{
"De um modo geral, podemos afirmar que o golpe de outubro de 1930 resultou no deslocamento da tradicional oligarquia paulista do centro do poder, ao mesmo tempo em que os demais setores sociais nele envolvidos e vitoriosos - as demais oligarquias agrárias não-exportadoras e os
} 
segmentos de classe média civis e militares - não tiveram condições, individualmente, de legitimar o novo Estado. Isto significa que (...) nenhuma outra das frações de classe envolvidas na "revolução" conseguira dar uma resposta adequada, demonstrando a dificuldade, por parte de qualquer uma delas, de impor seus interesses particulares como expressão dos interesses gerais da Nação.” (MENDONÇA, op. cit., p.14)

A deposição do Presidente Washington Luís pelas cúpulas do Exército e da Marinha, em outubro de 1930, e a posse de Getúlio Vargas na presidência, em novembro deste mesmo ano, como já assinalamos acima, marcam a crise da hegemonia da oligarquia cafeeira paulista em razão do esgarçamento do modelo econômico agrário-exportador, dependente de importações de manufaturados e bens de consumo.

O governo brasileiro, sob a condução de Getúlio Vargas, inaugura uma nova fase para as relações entre o Estado (estrito senso) e a sociedade civil ${ }^{6}$. A partir da ruptura interna do Estado Oligárquico - que não consegue acomodar as tensões e conciliar os interesses conflitantes de suas frações, o que aliás, está na raiz da ruptura política, econômica e social com esse mesmo Estado, que representou o golpe de 1930 - este deixa de atuar no sentido de defender e incentivar a produção ligada ao mercado externo, assume uma posição explícita de condenação ao liberalismo econômico e reconhece a necessidade de reorganização dos mercados de capital e força de trabalho. Nas palavras do próprio Vargas:

\begin{abstract}
"Examinando detidamente o fator de maior predominância na evolução social, penso não errar afirmando que a causa principal de falharem todos os sistemas econômicos, experimentados para estabelecer o equilíbrio das forças produtoras, se encontra na livre atividade permitida à atuação das energias naturais, isto é, na falta de organização do capital e do trabalho, elementos dinâmicos preponderantes no fenômeno da produção, cuja atividade cumpre, antes de tudo, regular e disciplinar." (VARGAS, 1942. Apud IANNI, 1996, p.31. Grifo nosso)
\end{abstract}

Ao mesmo tempo, nesse contexto, começavam a se fortalecer os grupos sociais recém surgidos, com interesses distintos dos interesses da burguesia nacional e internacional vinculada à cafeicultura: a burguesia industrial, o proletariado e a classe média. Cresce também o mercado interno, abrindo-se novas perspectivas para o ainda incipiente setor manufatureiro, que vai pouco a pouco substituindo com seus produtos as importações.

Essas novas forças políticas, surgidas no âmbito do Estado brasileiro, optaram claramente por políticas do tipo nacionalista para a solução dos problemas do país, principalmente em vista das limitações estruturais da dependência econômica já reveladas pelas frequentes crises da nossa economia agro-exportadora e também pelas próprias crises do capitalismo mundial (Primeira Guerra Mundial, Depressão Econômica e Segunda Guerra Mundial). Dentre essas opções políticas, a mais importante delas, sem dúvida, foi a adoção de uma política de intervenção do Estado na economia, no sentido de favorecer a nascente indústria brasileira e consolidar a economia capitalista nacional.

Desde seu início, o governo Vargas empreendeu várias medidas na linha de intervenção do Estado na economia, visando diferenciar e aparelhar o Estado e torná-lo mais eficiente em termos políticos e ideológicos ${ }^{7}$. Nesse sentido, em 26 de Novembro de 1930, extraiu-se do Ministério da Justiça e Negócios Interiores, setores que se constituiriam em dois novos ministérios: o Ministério do Trabalho, para "superintender a questão social", que deixava o âmbito da "ordem pública", com Lindolfo Collor a sua 
frente; e o Ministério da Educação e Saúde Pública, que tinha como objetivo - nas palavras do seu primeiro titular, Francisco Campos, no discurso de posse - "sanear e educar o Brasil (...) libertar os brasileiros". Cinco anos depois, seu sucessor no Ministério, Gustavo Capanema dizia também no seu discurso de posse, que o Ministério visava "melhorar o homem, na sua saúde, nas suas qualidades morais, nas suas aptidões intelectuais, para dele fazer um eficiente trabalhador" (CUNHA, 1983, p. 441 e 466). Apesar disso, IANNI (op.cit., p. 26) ressalta que, as medidas econômico-financeiras adotadas e as reformas político-administrativas realizadas, além da própria reestruturação do aparelho estatal não foram o resultado de um plano preestabelecido. Esse mesmo autor, chama atenção para o fato de que o governo foi dando resposta aos problemas e dilemas, na medida em que eles apareciam no seu horizonte político.

Nesse sentido, não se encontra, além de algumas poucas e fragmentadas referências, nada que se possa chamar de um projeto educacional pretendido pelo governo instituído pelo golpe de 1930. No âmbito do ensino secundário, nossa área de investigação, o programa da Aliança Liberal somente se referia a um maior "arejamento" e "atualização" de métodos e disciplinas, além de se referir, no item "questão social", à necessidade do proletariado urbano e rural ter educação e instrução, particularmente as ministradas pelas escolas técnico-industriais e agrárias. (CUNHA, 1983, p. 440)

Ainda segundo CUNHA (idem), a ausência de um projeto educacional articulado no programa da Aliança Liberal não se constituía em mera omissão, "mas era resultado da própria heterogeneidade das forças políticas e sociais que a compunham". A esse respeito, MENDONÇA (1988, p. 13-22) chama a atenção para a intensa polêmica que divide os historiadores em torno de duas controvérsias: “a) entre os que identificam e negam o caráter burguês da 'revolução' de 30; e b) entre os que avaliam o papel do Estado no pós30 ora como conservador, ora como modernizador da economia brasileira". A crise de hegemonia do grupo cafeeiro paulista, provocada pela impossibilidade de preservação do modelo agrário-exportador baseado no café, relacionada com a conjuntura internacional, desestabilizada pela crise de 29, cria:

"uma conjuntura favorável ao conjunto das forças sociais que, ao longo dos anos 20, questionavam a hegemonia paulista e o caráter excludente do regime político da chamada República Velha. Movimentos como os do tenentismo e as cisões oligárquicas são exemplos do descontentamento e das tensões sociais que se acumulavam e que desembocariam no movimento de 30". (MENDONÇA, op. cit., p. 13-4).

Naquele momento da história do Brasil, transitávamos de um modelo capitalista agrário-exportador - onde quase não havia demanda social por educação em decorrência mesmo das formas arcaicas de produção, aliadas à baixa densidade demográfica e de urbanização - para o capitalismo industrial que indubitavelmente, trazia novas exigências educacionais.

"A revolução de 30, resultado de uma crise que vinha de longe destruindo o monopólio do poder pelas velhas oligarquias, favorecendo a criação de algumas condições básicas para a implantação definitiva do capitalismo industrial no Brasil, acabou, portanto, criando também condições para que se modificassem o horizonte cultural e o nível de aspirações de parte da população brasileira, sobretudo nas áreas atingidas pela industrialização. É então que a demanda social de educação cresce e se 
consubstancia numa pressão cada vez mais forte pela expansão do ensino". (ROMANELLI, 1998, p. 60)

Ao mesmo tempo em que crescia a demanda social por educação, as elites, movidas por temores vinculados à luta de classes, - trazida também pela industrialização crescente - tentam conter a pressão popular pela democratização do ensino, resultando em uma política de expansão "controlada" da educação nacional, que não daria conta, nem quantitativamente, nem qualitativamente, das necessidades da população.

Foi nesse contexto que se deu a criação da Associação Brasileira de Educação $\mathrm{ABE}$ - em 1924, por um grupo de intelectuais preocupados com a situação da educação brasileira, assumindo uma importância muito grande nesse período, exercendo uma posição crítica e combativa com relação ao próprio governo, tendo sido um fórum de livres debates, altamente qualificados. A partir de 1926, a ABE faz acontecer uma série de Conferências Nacionais de Educação, produzindo vários documentos sendo o mais famoso deles, o Manifesto dos Pioneiros da Escola Nova de 1932.

Como nos mostra HORTA (1997, p. 139-140), somente no Manifesto dos Pioneiros aparece, de forma muito clara, a idéia da elaboração de um plano educacional para o Brasil. No entanto, pode-se concluir que o "plano de reconstrução educacional" apresentado em linhas gerais, é antes de tudo um plano de organização e de administração do sistema educacional, a partir de alguns princípios pedagógicos e administrativos, e não um "Plano Nacional de Educação", com objetivos, metas e previsão de recursos claramente definidos.

Após a pressão política sobre o governo, provocada pela "revolução constitucionalista" de $1932^{8}$, Vargas concedeu que se realizassem as eleições para a Assembléia Constituinte, em 5 de maio de 1933. Em função disso, se realizaria em Niterói, em dezembro de 1932 a V Conferência Brasileira de Educação promovida pela ABE, com o objetivo principal, segundo Fernando de Azevedo, de "apreciar sugestões de uma política escolar e de um plano de educação nacional para o anteprojeto da Constituição" (apud HORTA, 1997, p. 140). Desta conferência resultaram dois documentos: um anteprojeto do capítulo sobre Educação para a nova Constituição, a ser encaminhado à futura Assembléia Nacional Constituinte e um esboço de um Plano Nacional de Educação, com concepção idêntica à dos educadores liberais do Manifesto, ou seja, plano de organização e estruturação do sistema educacional, que de fato, influenciaram a Assembléia Nacional Constituinte na elaboração da parte referente à educação. A Constituição acabou sendo promulgada em 16 de julho de 1934. Simultaneamente, o Congresso realizou eleições indiretas e Vargas foi eleito.

No que diz respeito à política geral no Brasil nessa época, NOSELLA (1998, p. 177) denuncia seu caráter "populista" e "corporativista dirigista de modelo fascista" populismo surge "naturalmente" para administrar a crise e a tensão existentes entre o setor tradicional arcaico extrativista e o nascente setor moderno industrial ou os novos grupos sociais que vão se constituindo a partir das necessidades advindas da organização societária urbano-industrial.

O populismo teve seus méritos ao abrir a escola aos filhos das classes menos favorecidas, mas não ofereceu a escola necessária. Democratizou, mas não deu a qualidade necessária. Aproximou a classe trabalhadora da escola, mas não a integrou a ela; o diploma da escola "de faz-de-conta" equivale ao diploma da escola "boa", mas o ensino não equivale. Aquela é a escola dos dirigidos e esta é a escola dos dirigentes. 
Dando ao ensino um caráter paternalista, no sentido de que com ele, o trabalhador pode se afastar do trabalho braçal, mal pago, duro, o populismo acaba por mistificar o trabalho intelectual, o "não-trabalho".

Por outro lado e junto com o populismo, o corporativismo dirigista é introduzido com o objetivo de remover ou neutralizar os "elementos de conflito: a concorrência no plano econômico, a luta de classe no plano social, as diferenças no plano político". (BOBBIO, apud NOSELLA, op. cit., p. 177)

As ações no campo da educação, inspiradas no populismo e corporativismo dirigista, não passavam de um remédio "para 'cicatrizar' a dolorosíssima ferida de uma sociedade desigual, que para uns oferece a escola, para outros 'faz-de-conta' que oferece". (NOSELLA, ibid., p. 179).

Tudo isso, segundo NOSELLA (1993, p. 160-4), corroborava com o industrialismo de "marca americana", tardio, inorgânico, destrutivo e violento, "transplantado" para o Brasil na década de 30 pela política do governo de Getúlio Vargas, que veio formar a periferia e romper radicalmente a organicidade urbana que, de certa forma, já começava a existir. A periferia então, tomou características sociais diferentes daquelas dos antigos subúrbios e distritos, na época em que um núcleo de valores morais e culturais unitários cimentava a cidade como um todo, sem contudo ignorar as enormes diferenças, mas garantindo uma certa organicidade urbana. Nesse contexto, o "grupo escolar" público exercia uma função integradora até o aparecimento e o alastramento de escolas primárias (relativo às quatro primeiras séries do $1^{\circ}$ grau) particulares, antagônicas ao sistema educacional público de $1^{\circ}$ grau. A partir de então, essa ruptura se torna mais contundente, e a escola brasileira, no seu conjunto, começa a refletir o sistema produtivo que se apresentava como sendo uma mistura inorgânica de formas produtivas arcaicas (escravocratas) e de formas industriais destrutivas.

A estrutura e organização do sistema escolar brasileiro, a despeito de todas as reformas pelas quais passou no século $\mathrm{XX}$, apresenta como característica marcante, o ensino primário seguido pelo secundário, de caráter propedêutico, e o superior, dividido este sim, em ramos profissionais. A rigor, o ensino médio ou secundário de $2^{\underline{0}}$ ciclo, somente vai passar a existir como curso regular a partir da Reforma Gustavo Capanema, levada a cabo entre os anos de 1942 a 1947. Até antes da Reforma Francisco Campos em 1931/32, a estrutura e organização do ensino - apesar do fato de que até a década de 30, este nunca estivera organizado num sistema nacional, o que evidenciava a ausência mesmo de uma política nacional de educação até então - se dava, via de regra, com o curso primário com duração de quatro anos, que podia ser sucedido pelo curso ginasial com 5 anos de duração, pelo curso normal (um ano de duração), antecedido de dois anos de adaptação e o curso técnico comercial (um a três anos de duração), antecedido de três anos de curso preparatório.

Às camadas populares, aquelas que na divisão social e técnica do sistema produtivo executariam o trabalho pensado e organizado pela elite - funções que exigiam apenas algum nível de escolarização -, oferecia-se a alternativa dos cursos rural e profissional, ambos com a mesma duração do curso primário, muito embora não dessem aos seus concluíntes acesso ao curso Ginasial, mas respectivamente aos cursos básico agrícola e complementar, ambos com 2 anos de duração que não possibilitavam a continuidade dos estudos, ou seja, tinham um caráter de terminalidade, que, em termos gramscianos, seriam as escolas imediatamente interessadas no trabalho.

Somente àqueles que concluíssem a $5^{\mathrm{a}}$ série do curso ginasial, era permitido prestar os exames para um dos três cursos superiores, na época, medicina, direito e engenharia, após um período de estudos livres. Aqueles que não fizessem os estudos livres com vistas 
aos exames para um curso superior e optassem por cursar mais um ano - a $6^{\mathrm{a}}$ série recebiam o título de bacharel em Ciências e Letras.

Essa estrutura apresentava um caráter absolutamente classista e dual, refletindo o próprio caráter classista das formações sociais capitalistas e seus princípios no que diz respeito à divisão social do trabalho, como é possível visualizar pelo quadro abaixo:

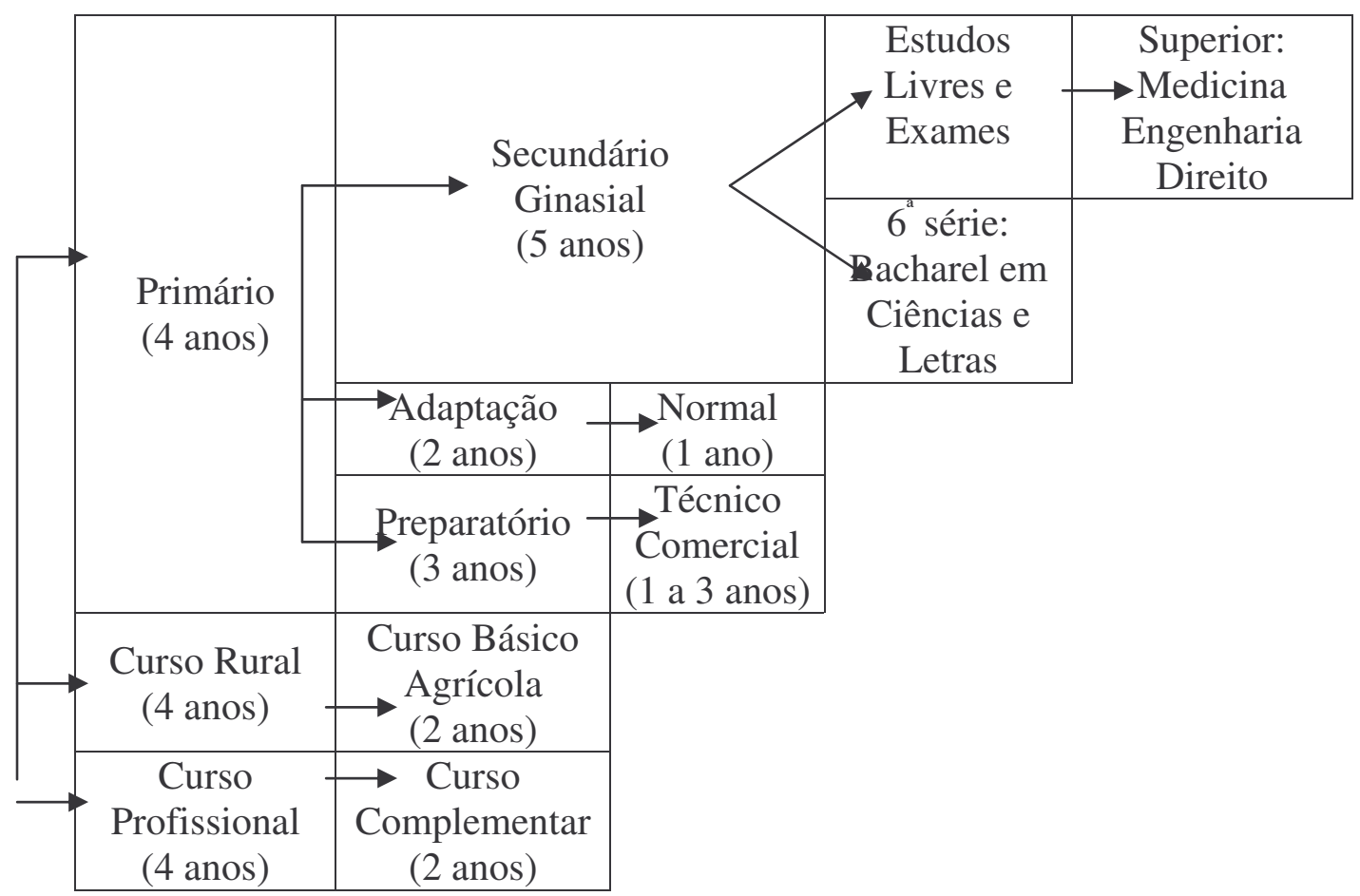

Quadro 1: Estrutura e organização do sistema escolar brasileiro até 1931 (antes da Reforma Francisco Campos). Elaboração do autor.

Aos cidadãos de "primeira categoria" ou à futura elite dirigente (os "tomadores de decisões"), era reservada a seqüência: primário, ginasial, estudos livres e exames e um curso superior; aos cidadãos de "segunda categoria", que iriam desempenhar funções intermediárias na divisão técnica e social do trabalho, eram reservadas as sequiências: primário, ginásio e $6^{\mathrm{a}}$ série; ou primário, adaptação e normal; ou ainda primário, preparatório e técnico comercial. Para os cidadãos de "terceira categoria", que teriam funções "menos intelectualizadas" no processo produtivo (KUENZER, 1997, p. 12-3), eram reservados os cursos rural, seguido do básico agrícola ou profissional, seguido do complementar.

Francisco Campos, inspirado no fascismo italiano, fincando os marcos de uma política educacional nacional e autoritária, em abril de 1931, cinco meses após a instituição do Governo Provisório e apenas quatro meses após sua posse no Ministério da Educação e Saúde Pública, decreta a Reforma do Ensino Secundário ${ }^{10}$, ampliando sua duração de cinco para sete anos e dividindo-o em dois ciclos. O primeiro, destinado ao curso fundamental, com duração de cinco anos, que teria o objetivo de fornecer aos "tomadores de decisões" a cultura geral necessária. O segundo ciclo, destinado ao curso complementar, com duração de dois anos, teria caráter preparatório aos vestibulares e currículos diferenciados para atender a este fim. 
Tais medidas se justificavam, segundo Francisco Campos, devido à suposta importância atribuída a este nível de ensino na "formação do homem para todos os grandes setores da atividade nacional, constituindo no seu espírito todo um sistema de hábitos e comportamentos que o habilitem a viver por si mesmo e a tomar em qualquer situação as decisões mais convenientes e seguras". Portanto, a articulação dessa finalidade própria do ensino secundário com a função propedêutica - de preparar candidatos para o ensino superior - foi baseada na preocupação de formar "indivíduos capazes de tomar decisões". (CUNHA, 1983, p. 442-3)

KUENZER (op. cit., p. 12-3) aponta que tal reforma pouco alterou a característica básica de estruturação e organização explicitamente dual e classista do sistema escolar brasileiro, apenas dando início, com a criação dos cursos complementares no $2^{\circ}$ ciclo do secundário, à estruturação do que seria, com a Reforma Capanema em 1942, denominado genericamente de cursos colegiais. Os cursos normal e técnicos comerciais, também foram expandidos, "sem contudo alcançar equivalência para fins de acesso aos cursos superiores". No entanto, os cursos agrícola e profissional permaneceram sem alterações.

Permanecia, portanto, bem demarcada a trajetória educacional dos cidadãos brasileiros de acordo com sua origem de classe, que determinava as suas funções na sociedade e no sistema produtivo, como nos é possível visualizar no quadro abaixo:

\begin{tabular}{|c|c|c|c|c|}
\hline \multirow{6}{*}{$\begin{array}{l}\text { Primário } \\
\text { (4 anos) }\end{array}$} & \multicolumn{3}{|c|}{ Secundário } & \multirow{2}{*}{ Superior } \\
\hline & \multicolumn{2}{|c|}{$1^{\circ}$ Ciclo } & $2^{\circ}$ Ciclo & \\
\hline & \multicolumn{2}{|c|}{$\begin{array}{l}\text { Fundamental } \\
\text { (5 anos) }\end{array}$} & $\begin{array}{c}\text { Complementares } \\
\text { (2 anos })\end{array}$ & $\begin{array}{l}\text { Medicina, Odontologia e } \\
\text { Farmácia } \\
\text { Engenharia e Arquitetura } \\
\text { Direito }\end{array}$ \\
\hline & $\begin{array}{l}\text { Adaptação } \\
\text { (2 anos) }\end{array}$ & $\begin{array}{l}\text { Normal } \\
(1 \text { ano })\end{array}$ & $\begin{array}{l}\text { Normal } \\
\text { Aplicação } \\
(2 \text { anos })\end{array}$ & $\begin{array}{c}\text { Normal } \\
\text { Aperfeiçoamento } \\
(2 \text { anos })\end{array}$ \\
\hline & \multicolumn{2}{|c|}{$\begin{array}{l}\text { Preparatório } \\
\text { (3 anos) }\end{array}$} & $\begin{array}{c}\text { Cursos Técnicos } \\
\text { Comerciais } \\
\text { (1 a } 3 \text { anos })\end{array}$ & $\begin{array}{c}\text { Administração e } \\
\text { Finanças } \\
\text { (3 anos })\end{array}$ \\
\hline & \multicolumn{2}{|c|}{$\begin{array}{l}\text { Auxiliar de Comércio } \\
\text { (2 anos) }\end{array}$} & & \\
\hline $\begin{array}{l}\text { Curso Rural } \\
\text { (4 anos) }\end{array}$ & \multicolumn{2}{|c|}{$\begin{array}{c}\text { Curso Básico } \\
\text { Agrícola } \\
\text { (2 anos })\end{array}$} & & \\
\hline $\begin{array}{c}\text { Curso } \\
\text { Profissional } \\
\text { (4 anos) }\end{array}$ & \multicolumn{2}{|c|}{$\begin{array}{c}\text { Curso } \\
\text { Complementar } \\
(2 \text { anos })\end{array}$} & & \\
\hline
\end{tabular}

Quadro 2: Estrutura e organização do sistema escolar brasileiro após a Reforma Francisco Campos (1931/32). Elaborado pelo Autor.

Apesar do seu mérito, por representar a primeira ação mais efetiva e objetiva do Estado em relação à educação e propor, pela primeira vez na história de nosso país, alterações profundas na estrutura e organização do ensino, a serem implantadas em todo o território nacional - o que representava na prática, nossa primeira política nacional para a educação -, a Reforma Francisco Campos apresentou também aspectos negativos, refletindo tensões e conflitos existentes entre os grupos que compunham o bloco no poder. 
Dentre esses aspectos, podemos citar seu caráter elitista-aristocrático, dada a obrigatoriedade dos exames de admissão ao ensino médio, a implantação de um sistema de avaliação arcaico e exageradamente rigoroso e os cuidados com o ensino secundário e superior voltado exclusivamente às carreiras liberais ${ }^{11}$. $\mathrm{O}$ ensino primário foi marginalizado, assim como no profissional, a Reforma tratou apenas do ramo comercial, marginalizando os vários outros ramos e o normal. Além disso, a Reforma Francisco Campos não estabeleceu articulação entre o secundário e o profissional, deixou de criar o ensino industrial, perdendo o "bonde" da transição entre os modelos econômicos, controlando e direcionando a expansão do ensino, de modo a não permitir a "extensão da educação escolarizada a todas as camadas" e ver ameaçados os "privilégios até então assegurados às elites". (ROMANELLI, 1998, p. 144)

Corroborando essa análise, veio no bojo da Reforma Francisco Campos, a criação do Conselho Nacional de Educação pelo Decreto n ${ }^{\circ} .19 .850$ de 11 de Abril de 1931, cuja composição apresentava representantes apenas dos ensinos superior e secundário (não havia no Conselho, representantes do magistério, do ensino primário e profissional), apesar de ter dentre suas atribuições fundamentais a de "firmar as diretrizes gerais do ensino primário, secundário, técnico e superior" (art. $5^{\circ}$, alínea 7, apud ROMANELLI, op. cit., p. 140/1. Grifos nossos).

A criação da Inspetoria do Ensino Profissional e Técnico em 1931 significava uma preocupação do Governo em dar uma organização mais sistêmica a essa modalidade de ensino. No entanto, somente em 1934, com sua transformação em Superintendência do Ensino Profissional, diretamente ligada ao ministro, é que ações nessa direção começam a ser efetivadas. Conforme ressaltou CUNHA (op. cit., p. 444), acabou representando a preparação do aparelho do Estado e a centralização de poder, para a tomada de medidas de maior alcance a partir de 1937, com a implantação do Estado Novo.

De fato, a Constituição de 1937 traz elementos que apontam para a organização sistematizada da educação profissional, muito embora, constitucionalizasse a dualidade e seu caráter classista, ao afirmar ser o ensino profissional destinado aos "pobres":

"O ensino pré-vocacional e profissional destinado às classes menos favorecidas, é em matéria de educação o primeiro dever do Estado. Cumpre-lhe dar execução a esse dever, fundando institutos de ensino profissional e subsidiando os de iniciativa dos Estados, dos Municípios e dos indivíduos ou associações particulares e profissionais. É dever das indústrias e dos sindicatos econômicos criar, na esfera de sua especificidade, escolas de aprendizes, destinadas aos filhos de seus operários ou de seus associados. A lei regulará o cumprimento desse dever e os poderes que caberão ao Estado sobre essas escolas, bem como os auxílios, facilidades e subsídios a lhes serem concedidos pelo poder público" (Constituição de 10 de Novembro de 1937, art. 129. Apud RAMOS, 1995, p. 69. Grifo nosso).

Como já assinalamos anteriormente, o governo brasileiro sob a condução de Getúlio Vargas, inaugura uma nova fase para as relações entre o Estado (estrito senso) e o sistema político-econômico (sociedade civil) e, particularmente, no que diz respeito às formas de intervenção do estado na economia, dá um vinco nacionalista e intervencionista a essas: 
“A intervenção do Estado no domínio econômico só se legitima para suprir as deficiências da iniciativa individual e coordenar os fatores de produção, de maneira a evitar ou resolver seus conflitos e introduzir no jogo das competições individuais o pensamento dos interesses da Nação, representados pelo Estado.

A intervenção do domínio econômico poderá ser mediata e imediata, revestindo a forma do controle, do estímulo ou da gestão direta" (Constituição de 1937, art. 135. Apud IANNI, 1996, p. 57. Grifo nosso).

Tais opções se colocavam no horizonte, diante de uma conjuntura de crise econômica e financeira de dimensões mundiais, que se refletiam no Brasil de forma contundente em face da nossa condição de economia periférica e dependente das economias do capitalismo central. Esses reflexos, ao mesmo tempo em que revelavam as limitações estruturais do modelo baseado numa economia primária exportadora, colocavam também em evidência "as possibilidades do sistema econômico e político brasileiro" (IANNI, op. cit., p. 70), levando o Estado a atuar mediante as transformações estruturais pelas quais o país passava:

\begin{abstract}
"A medida que se expandiam o setor terciário urbano e a industrialização incipiente, aumentava a classe média, o proletariado e a burguesia industrial. Em consequência, surgiam novos interesses econômicos, sociais e políticos. Conforme se intensificava a divisão social do trabalho e diversificava-se a sociedade urbana, o Estado era levado a defrontar-se com problemas e dilemas novos e, muitas vezes, mais complexos. Essas relações e correspondências entre as transformações da sociedade e do Estado (como componentes do mesmo sistema global) manifestavam-se de modo aberto nas situações de crise" (IANNI, ibid., p. 58).
\end{abstract}

Como vimos, a intensificação do capitalismo industrial no Brasil, ocorrida a partir da "Revolução" de 30 e a conseqüente complexificação da sociedade brasileira , acabou por determinar novas demandas no campo da educação, especialmente no campo da educação profissionalizante, trazendo modificações também nas próprias ações do Estado.

No plano da conjuntura internacional, a eclosão da Segunda Guerra Mundial traz complicadores que também obrigam o Estado a intervir, de modo a assegurar o atendimento das demandas internas, em face da circunstância de escassez de recursos, tecnologia e produtos disponíveis internacionalmente:

“(...) a Segunda Grande Guerra continuaria dificultando a rearticulação entre os centros e a 'periferia'. O mundo resultante do conflito vivia o problema crucial da reconstrução das economias dos países ex-inimigos e isto desviava recursos que poderiam se dirigir para as nações nãoindustrializadas do sistema, gerando um padrão de investimentos 'de centro a centro'. Dentro desta caracterização da divisão internacional do trabalho, continuava cabendo aos países do Terceiro Mundo o papel de produtores de matérias-primas e produtos agrícolas. A industrialização brasileira acelerada nesta etapa se realizaria, pois, nas brechas deste 'policentrismo' e a despeito dele" (MENDONÇA, 1988, p. 35). 
Esse processo de intensificação da industrialização no Brasil provoca alterações no perfil da estrutura industrial brasileira e, mais uma vez, recorremos a MENDONÇA (op. cit.: 33-4) para demonstrar tais tendências:

Tabela 1: Indicadores de Modificações Estruturais na Economia Brasileira

a) Estrutura do Produto Físico (a preços correntes):

\begin{tabular}{l|c|c|c}
\hline & 1907 & 1919 & 1939 \\
\hline Agricultura & $79 \%$ & $79 \%$ & $57 \%$ \\
\hline Indústria & $21 \%$ & $21 \%$ & $43 \%$ \\
\hline \multicolumn{4}{l}{}
\end{tabular}

b) Taxas Anuais de Crescimento:

\begin{tabular}{l|c|c|c}
\hline & Agricultura & Indústria & Total \\
\hline $1920-1929$ & $4,1 \%$ & $2,8 \%$ & $3,9 \%$ \\
\hline $1933-1939$ & $1,7 \%$ & $11,2 \%$ & $4,9 \%$ \\
\hline $1939-1945$ & $1,7 \%$ & $5,4 \%$ & $3,2 \%$ \\
\hline
\end{tabular}

Fonte: VILLELA, A. e SUZIGAN, W., 1975. Citado por MENDONÇA, 1988, p. 34

Nesse contexto, pode-se entender a política de intervenção do Estado no sentido de disciplinar, particularmente, a força de trabalho industrial, como condição necessária à aceleração do processo de industrialização, bem como o significado das Reformas levadas a cabo por Gustavo Capanema, que vão exatamente na direção de procurar garantir esse disciplinamento.

A partir da outorga da Constituição de 1937, em que era atribuída às empresas e também aos sindicatos a responsabilidade pela formação sistemática "dos filhos de seus operários ou de seus associados" (art. 129), em escolas de aprendizes, o Governo do Estado Novo, através da Divisão do Ensino Industrial do Ministério da Educação, elabora dois anteprojetos de lei em 1938, visando regulamentar o dispositivo constitucional. Um, criando as escolas de aprendizes industriais, mantidas e dirigidas pelas indústrias e sindicatos patronais, destinadas aos jovens trabalhadores com idade entre 14 e 18 anos e o outro, criando as escolas pré-vocacionais, também sob a responsabilidade dos sindicatos dos empregadores, para jovens não-trabalhadores, com idade entre os 11 e 14 anos.

O primeiro anteprojeto foi encaminhado ainda em 1938 às associações civis não sindicais dos empresários do setor industrial - a Confederação Nacional da Indústria e a Federação das Indústrias de São Paulo - que não se posicionaram, levando o Governo a decretar, em maio de $1939^{12}$, a obrigatoriedade das empresas em manterem cursos de aprendizagem para os jovens trabalhadores e de aperfeiçoamento profissional para os adultos. Ainda naquele ano, foi elaborado, por uma comissão interministerial (três representantes do Ministério da Educação e três representantes do Ministério do Trabalho), um anteprojeto de regulamentação do decreto que acabou não sendo encaminhado por conta da disputa acerca de qual Ministério teria o controle do sistema que se estava criando; foi substituído por um novo decreto, de julho de $1940^{13}$, através do qual o controle ficava a cargo do Ministério da Educação. Nele, os jovens sujeitos à aprendizagem eram definidos como trabalhadores, aos quais seriam devidos salários e os custos da implantação e manutenção das escolas ficava integralmente atribuídos aos empresários. Todo esse processo, culminou com a publicação, em 22 de Janeiro de 1942, do Decreto-lei $\mathrm{n}^{\circ}$ 4.048, 
que criava o Serviço Nacional de Aprendizagem Industrial (SENAI). (CUNHA, 1983, p. $450-4)^{14}$

Nesse período, a burguesia industrial vinha importando quadros técnicos para dar conta da implantação e expansão de suas empresas, tendo em vista que até aquele momento, não havia uma política nacional adequada de formação de força de trabalho. No entanto, como já dissemos, a Guerra não só provocava dificuldades nesse nível, como também no nível do abastecimento de produtos industrializados. Diante desse quadro, o Governo articulava a criação de um modelo que viesse acelerar a substituição das importações e que permitisse a satisfação da população com produtos de fabricação nacional. Isso implicava, obviamente, a adoção de um modelo que viesse, também, acelerar a expansão do setor industrial, o que de outro lado, trazia a necessidade de formar, em nosso próprio país, a força de trabalho a ser então absorvida e incumbida dessa tarefa.

No entanto, o Governo não havia dotado o sistema educacional brasileiro da infraestrutura necessária para tal missão e nem tinha recursos para isso. Daí que resolve então criar esse sistema paralelo ao sistema oficial, "obrigando" 15 a burguesia industrial a formar seus quadros técnicos necessários, ao mesmo tempo que criava, no sistema oficial, as bases para que o mesmo pudesse também assumir parte dessa tarefa, pela publicação das "Leis" Orgânicas, da qual trataremos a seguir e, em especial da "Lei" Orgânica do Ensino Industrial.

Desde 1937, uma comissão de "notáveis", instituída e presidida pelo Ministro da Educação de Vargas, Gustavo Capanema, se encarregava de elaborar um conjunto de $\operatorname{Decretos}^{16}$, com vistas a reformar e padronizar todo o sistema nacional de educação. Esse conjunto de reformas, ficou conhecido como "Leis" Orgânicas do Ensino e foram baixadas entre os anos de 1942 e $1946^{17}$.

Com a Lei Orgânica do Ensino Secundário, esse grau de ensino permanece dividido em dois ciclos, sendo que o $1^{\circ}$ ciclo corresponde ao curso ginasial, com duração reduzida para 4 anos e com o objetivo de "dar aos adolescentes os elementos fundamentais do ensino secundário" (Art. $3^{\circ}$ ). No artigo 10, são listadas as disciplinas do curso ginasial, que em tese, dariam conta dos tais elementos fundamentais do ensino secundário que seriam línguas (português, latim, francês, inglês), ciências (matemática, ciências naturais, história geral, história do Brasil, geografia geral, geografia do Brasil) e artes (trabalhos manuais, desenho, canto orfeônico), além da educação física, "obrigatória para todos os alunos, até a idade de vinte e um anos" (art. 19), da educação militar, da educação religiosa e da educação moral e cívica. No artigo 23, fica clara a dualidade quando é explicitado que "é finalidade do ensino secundário formar as individualidades condutoras...". Para a matrícula no curso ginasial, os candidatos deveriam satisfazer três condições (art. 32):

口 ter pelo menos onze anos completos, ou por completar até o dia 30 de junho;

- ter recebido satisfatória educação primária;

- ser considerado apto nos exames de admissão.

Os cursos complementares do $2^{\circ}$ ciclo do secundário, instituídos pela Reforma Francisco Campos, são substituídos pelos cursos científico e clássico, cada qual com três anos de duração e com o objetivo de "consolidar a educação administrada no curso ginasial e bem assim desenvolvê-la e aprofundá-la" (art. $4^{\circ}$ ). O curso clássico concorreria para a formação intelectual, com ênfase no estudo de filosofia e letras antigas; enquanto que o curso científico, teria um aprofundamento maior no campo das ciências. $\mathrm{O}$ art. 12 define as disciplinas componentes dos currículos desses cursos que seriam as seguintes: línguas (português, latim, grego, francês, inglês, espanhol), ciências e filosofia (matemática, física, 
química, biologia, história geral, história do Brasil, geografia geral, geografia do Brasil, filosofia) e arte (desenho). Para dar conta das ênfases desejadas na distinção entre os dois cursos, as disciplinas de latim e grego somente seriam ministradas no curso clássico, enquanto que a disciplina de desenho seria ministrada somente no curso científico. As demais seriam comuns aos dois cursos, além da educação física, da educação militar, da educação religiosa e moral e cívica.

Para a matrícula nos cursos clássico e científico, além de não ser portador de doença contagiosa e ser vacinado, o candidato, segundo o art. 33 do decreto, deveria ter concluído o curso ginasial.

Esses cursos - clássico e científico - davam acesso ao ensino superior, desde que seus concluintes, fossem considerados aptos nos exames de licença.

\begin{tabular}{|c|c|}
\hline \multicolumn{2}{|c|}{ Secundário } \\
\hline $1^{\circ}$ Ciclo & $2^{\circ}$ Ciclo \\
\hline \multirow{3}{*}{ Ginasial } & Clássico \\
$(4$ anos $)$ & Científico $)$ \\
\cline { 2 - 2 } & $(3$ anos $)$ \\
\hline
\end{tabular}

Quadro 3: Estrutura e organização dada ao Ensino Secundário pela "Lei" Orgânica do Ensino Secundário (Decreto-lei no 4.244 de 09 de Abril de 1942)

No que diz respeito à educação profissional e tecnológica, focalizamos nossa análise na estrutura, organização, fins e objetivos do ensino industrial, objeto de reforma levada a cabo pela "Lei" Orgânica do Ensino Industrial, que o define como sendo "o ramo de ensino, de grau secundário, destinado à preparação profissional dos trabalhadores da indústria e das atividades artesanais, e ainda dos trabalhadores dos transportes, das comunicações e da pesca" (art. $1^{\circ}$ ). Sua destinação, quase que exclusiva, à classe trabalhadora, concretizando a dualidade estrutural do sistema educacional brasileiro, fica explicitada no seu art. $4^{\circ}$ onde são colocadas suas finalidades:

- Formar profissionais aptos ao exercício de ofício e técnicas nas atividades industriais;

- Dar a trabalhadores jovens e adultos na indústria, não diplomados ou habilitados, uma qualificação profissional que lhes aumente a eficiência e a produtividade;

- Aperfeiçoar ou especializar os conhecimentos e capacidades de trabalhadores diplomados ou habilitados;

- Divulgar conhecimentos de atualidades técnicas.

Quanto à organização do ensino industrial, a "Lei" orgânica dividiu-o em dois ciclos, sendo o primeiro, compreendido pelas seguintes "ordens de ensino": 1) Ensino Industrial Básico, onde se encontravam os "cursos industriais", com duração de quatro anos; 2) Ensino de Mestria, onde se encontravam os "cursos de mestria", com duração de dois anos; 3) Ensino Artesanal, onde estavam os "cursos artesanais", com duração de um ou dois anos e 4) Aprendizagem, onde se encontravam os "cursos de aprendizagem", com duração de um, dois, três ou quatro anos. O segundo ciclo compreendia as seguintes "ordens de ensino": 1) Ensino Técnico, onde se encontravam os "cursos técnicos" (mecânica, metalurgia, química, eletrotécnica, eletrônica e outros), com duração de três 
anos podendo ser seguido de um quarto ano de estágio supervisionado em uma indústria e 2) Ensino Pedagógico, onde estavam os "cursos pedagógicos", com duração de um ano, destinados "à formação de pessoal docente e administrativo do ensino industrial" (art. 10, § $\left.2^{\circ}\right)$.

Ressalte-se que todos os cursos do ensino industrial, como preconizava a "lei" orgânica em seus artigos $5^{\circ}$, item 3; 24; 64, item III e artigo 67 item VII, abrangeriam disciplinas de cultura geral e de cultura técnica, além das práticas educativas mencionadas no artigo 26.

No que diz respeito às escolas de aprendizagem ou aos cursos de aprendizagem, ressalvando o que diz a "lei" quanto ao tipo de estabelecimentos de ensino onde os mesmos poderiam ser ministrados, cabe ressaltar, como bem o faz ROMANELLI (1998, p. 155), que apesar de, com a "lei", o Governo procurar aparelhar e sistematizar o ensino industrial, ele acaba, também, reforçando a incumbência dada à burguesia industrial no que diz respeito à sua contribuição para a formação da força de trabalho necessária, conforme o artigo 67:

\footnotetext{
“Art. 67. O ensino industrial das escolas de aprendizagem será organizado e funcionará, em todo o país, com observância das seguintes prescrições:

O ensino de ofícios, cuja execução exija formação profissional, constitui obrigação dos empregadores para com os aprendizes, seus empregados.

Os empregadores deverão permanentemente, manter aprendizes, a seu serviço, em atividade cujo exercício exija formação profissional.

As escolas de aprendizagem serão administradas, cada qual separadamente, pelos próprios estabelecimentos industriais a que pertençam, ou por serviços, de âmbito local, regional ou nacional, a que se subordinem as escolas de serviço, em atividades cujo exercício exija formação profissional.

As escolas de aprendizagem serão localizadas nos estabelecimentos industriais a cujos aprendizes se destinem, ou na sua proximidade.
}

As escolas de aprendizagem darão cursos extraordinários, para trabalhadores que não estejam recebendo aprendizagem (...)." (Grifo nosso).

ROMANELLI (idem) conclui dizendo que “(...) Esse fato decorreu da impossibilidade de o sistema de ensino oferecer a educação profissional de que carecia a indústria e da impossibilidade de o Estado alocar recursos para equipá-lo adequadamente". No entanto, há outras interpretações para esse fato, como por exemplo, a que afirma ser este o início explícito da política de "parceria" entre o Estado e a burguesia industrial, onde o primeiro, cuida diretamente da formação para o trabalho complexo, enquanto o segundo, cuida da formação para o trabalho simples industrial. Tal interpretação é reforçada quando, por exemplo, verificamos também a necessidade tanto da indústria quanto do comércio, em termos de força de trabalho (para a execução de trabalho simples), a ser formada em pouco tempo.

Quanto aos tipos de certificação devida aos diferentes cursos, a "lei" garantia que aos concluintes de qualquer um dos "cursos industriais", seria conferido o diploma de "artífice"; aos que concluíssem qualquer um dos "cursos de mestria", seria conferido o 
diploma de "mestre"; seria conferido, aos que concluíssem "qualquer do cursos técnicos ou pedagógicos, o diploma correspondente à técnica, ou à ramificação pedagógica estudadas" (art. 16). O artigo 17 garantia um "certificado" mediante "a conclusão de qualquer dos demais cursos de formação profissional ou qualquer curso extraordinário".

Pode-se perceber que, para além do dualismo entre os "sistema regular de ensino" (ensino primário, secundário e superior) e o "sistema de educação profissional", existia, mesmo dentro da estrutura montada para o Ensino Industrial, uma discriminação caracterizada pelos vários "graus" a que poderiam chegar seus estudantes, de acordo com sua trajetória: uns poderiam obter o "grau" de "técnicos", outros de "mestres", outros ainda poderiam se tornar "artífices"; enquanto que, aos que fizessem os cursos "extraordinários", seria devido apenas um "certificado".

Para atender a essa "nova" organização do ensino industrial, foi necessário definir os tipos de estabelecimentos de ensino, cuja finalidade seria a de ministrar os cursos deste ramo da educação. Desta forma, a "lei" estabeleceu os seguintes tipos de escolas (art. 15 e seus parágrafos):

- Escolas técnicas para os cursos técnicos, de aperfeiçoamento e de especialização, destinados a professores e administradores, podendo ainda ministrar os cursos industriais, de mestria e pedagógicos;

- Escolas industriais para ministrar os cursos industriais, podendo ainda ministrar os cursos de mestria e pedagógicos;

- Escolas artesanais para os cursos artesanais;

- Escolas de aprendizagem para os cursos de aprendizagem, ressalvando que estes poderiam ser dados em qualquer outro estabelecimento de ensino industrial.

Com relação ao deslocamento do ensino profissional para o secundário, como determinava a legislação, a intenção do legislador era possibilitar a seleção dos alunos mais "educáveis", ao contrário do que acontecia com as escolas de aprendizes-artífices, de antes da "lei" orgânica. No artigo 18, item II, é explicitada essa intenção quando se fala da possibilidade de "um recrutamento bem orientado". Pelo fato das novas escolas industriais exigirem a aprovação em "exames vestibulares", além da aprovação em testes de aptidão física e mental, "a pobreza deixava de ser, então, critério suficiente para o aprendizado de um ofício, embora não perdesse seu caráter necessário”. (CUNHA, 1983, p. 459)

Ainda em relação ao deslocamento de todo o ensino industrial para o grau secundário, determinado pela "lei" orgânica, o curso primário passa a ser pré-requisito mínimo para o ingresso nos cursos do $1^{\circ}$ ciclo deste ramo do ensino, de modo que os cursos de formação profissional do primeiro ciclo do ensino industrial se articulavam ao ensino primário e os cursos técnicos com o ensino secundário de $1^{\circ}$ ciclo, ou seja, com o curso ginasial. A "lei", em seus artigos 29 e 30 determinava que "os candidatos à matrícula na primeira série de qualquer dos cursos industriais, de mestria, ou técnicos, ou na única série dos cursos pedagógicos", além de provar não serem portadores de doença contagiosa, serem vacinados e se mostrarem aptos nos exames vestibulares, deveriam:

1) Para os cursos industriais ( $1^{\circ}$ ciclo):

口 Terem entre doze e dezessete anos de idade;

- Terem concluído o curso primário.

2) Para os cursos de mestria ( $1^{\circ}$ ciclo):

a Terem concluído o curso industrial correspondente ao curso de mestria pretendido; 
3) Para os cursos técnicos ( $2^{\circ}$ ciclo):

a Terem concluído o curso ginasial $-1^{\circ}$ ciclo do ensino secundário - ou curso industrial relacionado com o curso técnico pretendido;

4) Para os cursos pedagógicos $\left(2^{\circ}\right.$ ciclo):

口 Terem concluído quaisquer dos cursos de mestria ou técnicos.

Apesar dessa articulação, aos concluintes dos cursos industriais da "ordem" Ensino Básico Industrial, era vedada a passagem para o $2^{\circ}$ ciclo do ensino secundário (cursos clássico ou científico), mesmo levando em conta, que os alunos cursavam disciplinas de cultura geral equivalentes a uma parte do conteúdo do $1^{\circ}$ ciclo do ensino secundário (curso ginasial). Desta forma, mais uma vez, estava explícito, a cidadãos de qual classe destinavam-se os cursos profissionalizantes do grau médio. A dualidade expressava-se, ainda, pela possibilidade de ingresso no ensino superior, dos concluintes de curso técnico, apenas em "curso diretamente relacionado ao curso técnico concluído, verificada a satisfação das condições de preparo, determinadas pela legislação competente" (art. 18, item III). A "lei" não deixa claro que cursos seriam esses e, somente em 1953, com a publicação da "Lei de Equivalência", esses cursos são definidos como sendo os de engenharia, química, arquitetura, matemática, física e desenho.

Quadro 4: Estrutura e organização dada ao Ensino Industrial pela "Lei" Orgânica do Ensino Industrial e sua articulação com as demais modalidades de ensino (Primário e Secundário):

\begin{tabular}{|c|c|c|c|c|c|}
\hline \multirow{8}{*}{$\begin{array}{l}\text { Curso } \\
\text { Primário }\end{array}$} & \multicolumn{4}{|c|}{ Industrial (Cursos Ordinários - de Formação Profissional) } & $\begin{array}{c}\text { Industrial } \\
\text { (Extraordinários) }\end{array}$ \\
\hline & \multicolumn{2}{|c|}{$1^{\circ}$ Ciclo } & \multicolumn{2}{|c|}{$2^{\circ}$ Ciclo } & \multirow{4}{*}{$\begin{array}{c}\text { Cursos de } \\
\text { Especialização } \\
\\
\text { Cursos de } \\
\text { Aperfeiçoamento }\end{array}$} \\
\hline & \multirow{3}{*}{ Cursos Industriais } & \multirow{3}{*}{$\begin{array}{l}\text { Cursos de } \\
\text { Mestria }\end{array}$} & $\begin{array}{l}\text { Cursos } \\
\text { Técnicos }\end{array}$ & $\begin{array}{l}\text { Cursos } \\
\text { Pedagógicos }\end{array}$ & \\
\hline & & & $\begin{array}{l}\text { Cursos } \\
\text { Técnicos }\end{array}$ & \begin{tabular}{|l} 
Cursos \\
Pedagógicos
\end{tabular} & \\
\hline & & & $\begin{array}{l}\text { Cursos } \\
\text { Pedagógicos }\end{array}$ & & \\
\hline & \multicolumn{2}{|l|}{\begin{tabular}{|l} 
Cursos Artesanais \\
\end{tabular}} & & & \\
\hline & \multicolumn{2}{|c|}{ Cursos de Aprendizagem } & & & \\
\hline & \multicolumn{5}{|c|}{ Cursos de Continuação } \\
\hline & \multicolumn{2}{|c|}{ Secundário ( $1^{\circ}$ Ciclo $)$} & \multicolumn{2}{|c|}{ Industrial $\left(2^{\circ}\right.$ Ciclo $)$} & $\begin{array}{c}\text { Industrial } \\
\text { (Extraordinários) }\end{array}$ \\
\hline $\begin{array}{l}\text { Curso } \\
\text { Primário }\end{array}$ & \multicolumn{2}{|c|}{ Ginásio } & $\begin{array}{l}\text { Cursos } \\
\text { Técnicos }\end{array}$ & $\begin{array}{c}\text { Cursos } \\
\text { Pedagógicos }\end{array}$ & $\begin{array}{l}\text { Aperfeiçoamento/ } \\
\text { Especialização }\end{array}$ \\
\hline
\end{tabular}

Obs.: Ressalvado o disposto no artigo 70:

“Art. 70. O portador de certificado de habilitação conferido por motivo de conclusão de curso artesanal de dois anos, ou de curso de aprendizagem 
de dois anos pelo menos, poderá matricular-se na segunda série de curso industrial que ministre o ensino do mesmo ofício, mediante a prestação de exames vestibulares especiais."

\section{Considerações Finais}

Apesar de reconhecer que as políticas de formação da força de trabalho levadas a efeito no Brasil, não favoreceram somente as classes dominantes e confundiram-se no mais das vezes, à história de luta da classe trabalhadora, na busca de soluções que contemplassem suas necessidades, não podemos deixar de constatar também, que elas foram construídas mediadas pela construção das diversas formas de sociabilidade capitalista nas quais o Estado desempenhou importante função.

Foi assim desde a primeira fase do chamado período desenvolvimentista (de 1930 a 1945) que analisamos nesse texto, em que o Estado brasileiro se deslocando entre o intervencionismo nacionalista e o intervencionismo liberalizante/subordinado, colocava sempre no centro de suas políticas, a formação da força de trabalho como um dos pilares do desenvolvimento, usando-a para (re)produzir o capital humano de que precisava para dar conta de seus projetos setoriais, ao mesmo tempo em que a usava para tentar obter o consenso das camadas populares.

Nesse sentido, é que contextualizamos aqui as Reformas Francisco Campos e Capanema, que deu origem à criação do SENAI, do SENAC e das escolas técnicas, situando-as como marcos da formalização da dualidade estrutural no sistema educacional brasileiro e como ações que buscaram disciplinar a formação da força de trabalho industrial que, sob a ótica do capital, eram necessárias para acelerar o processo de industrialização pelo qual o país passava.

Apesar do mérito de terem representado as primeiras ações efetivas do Estado em relação à educação e propor, pela primeira vez na história de nosso país, alterações profundas na estrutura e organização do ensino, a serem implantadas em todo o território nacional - o que de fato as transformavam em nossas primeiras políticas nacionais para a educação, elas não se constituíram em políticas públicas voltadas à superação das diferenças de classe. Pelo contrário, ao definirem trajetórias educacionais distintas para classes sociais também distintas, acabaram por se tornarem mecanismos destinados a perpetuar as diferenças dos grupos sociais.

Muito embora as instituições de ensino profissionalizante oferecessem aos seus alunos um currículo com conteúdos de formação geral, estes não se articulavam aos conteúdos de formação técnica, além de não garantirem - ou, pelo menos, dificultarem - a continuidade dos estudos fora deste ramo de ensino. Isto é, num duplo sentido, se articulavam aos interesses do capital, especialmente do capital industrial que ganhava força naquele momento histórico, ao servirem como processos de formação da força de trabalho industrial, a ser subjugada pelo capital no interior das relações sociais de produção capitalista, ao mesmo tempo em que buscavam obter o consenso ativo dos trabalhadores pela via da oferta de uma formação desejada por eles, embora com um caráter terminal, limitador, nem sempre percebido, e que, em última instância, manteria - ou aprofundaria sua situação de classe. 


\section{Referências Bibliográficas:}

BOBBIO, Norberto et alii. Dicionário de política. Brasília: EDUNB, 1992.

BOCAYUVA, Pedro Claudio Cunca e VEIGA, Sandra Mayrink. Novo vocabulário político. Petrópolis/Rio de Janeiro: FASE/Vozes, 1992. (Vol. I).

BRASIL. Decreto-lei nº 7.566 de 23 de Setembro de 1909.

. Decreto n ${ }^{\circ} .19 .850$ de 11 de Abril de 1931.

Decreto n ${ }^{\circ} .19 .890$ de 18 de Abril de 1931.

. Decreto $n^{\circ} .21 .241$ de 14 de Abril de 1932.

. Decreto-Lei $n^{\circ}$. 4.048 de 22/01/42 - Cria o SENAI.

. Decreto-Lei no. 4.073 de 30/01/42 - "Lei” Orgânica do Ensino Industrial

. Decreto-Lei no. 4.244 de 09/04/42 - "Lei” Orgânica do Ensino Secundário.

. Decreto-Lei n”. 6.141 de 28/12/43 - "Lei” Orgânica do Ensino Comercial

. Decreto-Lei n’. 8.529 de 02/01/46 - "Lei”" Orgânica do Ensino Primário

. Decreto-Lei no. 8.530 de 02/01/46 - "Lei”" Orgânica do Ensino Normal

. Decretos-Lei $n^{\circ}$ s. 8.621 e 8.622 de 10/01/46 - Criam o Serviço Nacional de Aprendizagem Comercial.

Decreto-Lei no. 9.613 de 20/08/46 - "Lei” Orgânica do Ensino Agrícola. Lei $n^{\circ} .9 .394$ de 20 de Dezembro de 1996 - Lei de Diretrizes e Bases da Educação.

Projeto de Lei $n^{\circ}$. 1.603/96.

Decreto $\mathrm{n}^{\circ} .2 .208$ de 17 de abril de 1997.

Decreto $n^{\circ} .5 .154$ de 23 de julho de 2004.

Lei $n^{\circ} .11 .741$ de 16 de julho de 2008.

CUNHA, Luis Antonio. A política educacional e a formação da força de trabalho industrial na era de Vargas. In: A Revolução de 30: Seminário realizado pelo Centro de Pesquisa e Documentação de História Contemporânea do Brasil (CPDOC) da Fundação Getúlio Vargas, Rio de Janeiro, Setembro de 1980. Brasília: Ed. Universidade de Brasília, 1983.

CURY, C. R. J. A educação e a primeira Constituinte republicana. In: FÁVERO, Osmar (Org.) A educação nas constituintes brasileiras 1823-1988. Campinas, SP: Autores Associados, 1996. (Coleção Memória da Educação).

FONSECA, Celso Suckow. História do ensino industrial no Brasil. Rio de Janeiro: SENAI, 1986.

GRAMSCI, Antonio. Maquiavel, a política e o Estado moderno. $3^{\text {a }}$ Ed., Rio de Janeiro: Civilização Brasileira, 1978. 1995. Concepção Dialética da História. $10^{\text {a }}$ Ed., Rio de Janeiro: Civilização Brasileira, 
HORTA, J. S. B. Plano Nacional de Educação: da Tecnocracia à participação Democrática. In: CURY, C. R. J., HORTA, J. S. B. E BRITO, V. L. A., Medo à liberdade e compromisso democrático: LDB e Plano Nacional de Educação. São Paulo: Ed. Do Brasil, 1997.

IANNI, Octávio. Estado e planejamento econômico no Brasil. $6^{\mathrm{a}}$ ed., Rio de Janeiro: Civilização Brasileira, 1996.

KUENZER, Acacia Zeneida. A Educação de $2^{\circ}$ grau - O trabalho como princípio educativo. São Paulo: Cortez e Autores Associados, 1988.

Ensino médio e profissional: as políticas do Estado neoliberal. São Paulo: Cortez, 1997. (Coleção Questões da nossa época; v. 63).

MANACORDA, M. História da Educação: da Antigüidade aos nossos dias. São Paulo: Cortez/Autores Associados, 1989.

MENDONÇA, Sonia Regina de. Estado e economia no Brasil: opções de desenvolvimento. Rio de Janeiro: Graal, 1988.

NOSELLA, Paolo. A Escola brasileira de final de século: um balanço. In: FRIGOTTO, G. (org.) Educação e crise do trabalho: perspectivas de final de século. Petrópolis: Vozes, 1998. (Coleção estudos culturais em educação)

A modernização da produção e da escola no Brasil - O estigma da relação escravocrata. Cadernos ANPEd, $\mathrm{n}^{\mathrm{O}}$ 5, Porto Alegre, 1993.

RAMOS, Marise Nogueira. Do ensino técnico à educação tecnológica: (a)-historicidade das políticas públicas dos anos 90. Niterói, 1995. Dissertação (Mestrado em Educação) UFF.

RODRIGUES, José. O Moderno Príncipe Industrial: o pensamento pedagógico da Confederação Nacional da Indústria. Campinas, SP: Autores Associados, 1998.

ROMANELLI, Otaíza de Oliveira. História da educação no Brasil (1930/1973). 21ª ed., Petrópolis, RJ: Vozes, 1998.

SAVIANI, Demerval. A nova lei da educação: trajetória, limites e perspectivas. 4 a ed., Campinas, SP: Autores Associados, 1998. (Coleção Educação Contemporânea).

\section{Notas:}

$1 \mathrm{O}$ conceito de dualidade utilizado nesse texto se identifica com o conceito de dualidade estrutural no sentido da existência de estruturas de ensino médio diferenciadas, desarticuladas e não equivalentes, que se destinam, uma à preparação para o ensino superior, portanto, com caráter propedêutico e outra, destinada à profissionalização de nível elementar e médio, com caráter, portanto, de terminalidade. (Para uma análise mais detalhada a esse respeito, ver KUENZER, 1988 e MANACORDA, 1989).

2 Trabalho enquanto categoria ontológica, através da qual o homem em conjunto com os outros homens trabalha a natureza, adaptando-a a si de modo a produzir as condições necessárias à sua existência e satisfazer suas necessidades. Nesse processo, ao modificar a natureza, o homem também se modifica e se desenvolve enquanto ser social, enquanto síntese das relações sociais que desenvolve na produção da sua existência.

3 Conceito de Estado utilizado aqui, se identifica com o conceito de Estado ampliado de matriz gramsciana, que deriva do desenvolvimento da contradição política entre governantes e governados, resultado do processo de socialização política decorrente da modernização econômica e do sistema de classes, particularmente a partir da presença de um pólo forte de pressão e demandas operárias 
e dos trabalhadores. Esse Estado ampliado é composto de duas esferas: i) a sociedade política (Estado estrito senso), formada pelo conjunto dos mecanismos e aparelhos repressivos do Estado controlados pelas burocracias executiva e policial-militar, através dos quais a classe no poder exerce a dominação através da coerção; e ii) a sociedade civil, formada por uma rede de aparelhos privados de hegemonia, ou seja, organismos sociais coletivos, relativamente autônomos frente à sociedade política, responsáveis pela elaboração e/ou difusão das ideologias, onde as classes buscam ganhar aliados para seus projetos e portanto, onde se encontra a possibilidade da formação de novas fontes de legitimidade, novas áreas de consenso. Assim, o Estado é considerado mais do que coerção; trata-se de coerção revestida por consenso. (BOCAYUVA e VEIGA, 1992). Para corroborar, usemos a definição do próprio GRAMSCI (1978, p. 87) para o conceito de Estado: "é todo o complexo de atividades práticas e teóricas com as quais a classe dirigente justifica e mantém não só o seu domínio, mas consegue obter o consentimento ativo dos governados".

4 Criadas pelo Decreto-lei no 7.566 de 23 de Setembro de 1909.

5 A primeira de caráter público em todo o continente americano foi criada em 1830 em Niterói. Em 1881 já eram pelo menos 10 e em 1949 totalizavam 540 espalhadas por todo o território nacional. (ROMANELLI, 1998, p. 163)

6 No âmbito dessas relações, particularmente nos interessa mais, os rumos que tomaram as formas de intervenção do Estado na economia a partir de então. É sobre elas que nos debruçaremos.

7 A partir do significado que Gramsci nos dá para a categoria ideologia, como sendo “(...) uma concepção do mundo, que se manifesta implicitamente na arte, no direito, na atividade econômica, em todas as manifestações de vida individuais e coletivas (...)" (GRAMSCI, 1995, p. 16), não podemos considerá-la como sendo simplesmente um "falseamento do real”, mas sim como “(...) uma concepção da necessidade que fornece à própria ação uma direção consciente." (Idem). Nesse sentido, quando falamos em tornar o Estado mais eficiente em termos políticos e ideológicos, falamos em tornar o Estado mais eficiente na busca para a obtenção do consenso da sociedade civil no que diz respeito aos seus projetos, oriundos das concepções de mundo das forças que o compõem.

8 Revolta patrocinada pela oligarquia paulista com o apoio de políticos de outros estados como Borges de Medeiros, que com o pretexto de exigir do Governo Federal a reconstitucionalização do país, pretendia reassumir o poder através de eleições controladas pelo coronelismo. O movimento foi derrotado e Medeiros, preso.

9 Para minimizar as polêmicas, resolvemos ressaltar aqui, que o termo "populismo", é tomado como sendo uma "fórmula política", que tem como núcleo ideológico exatamente a função de tentar conciliar restauração e modernização. Como assinala BOBBIO (1992, p. 984-6), "o populismo é o recurso natural de uma sociedade em crise, dividida entre o setor tradicional e o setor moderno (...) que tende a permear ideologicamente os períodos de transição, particularmente na fase aguda dos processos de industrialização" ou, que surge "sempre que ocorre uma rápida mobilização de vastos setores sociais, uma politização à margem dos canais institucionais existentes". Dentre as categorias em que são agrupados os movimentos populistas (nacional-populismo, populismo revolucionário e populismo democrático ou pluralista), o autor classifica o "getulismo" do Brasil, "sobre cujo caráter populista fundamental não pode haver dúvidas" (grifo nosso), como sendo uma forma intermediária às categorias indicadas. Quanto ao Corporativismo fascista, Vallauri (apud BOBBIO, op. cit., p. 289) afirma que o mesmo, "nasce como exigência das classes dirigentes de uma sociedade que, com o passar de um estágio agrícola a um estágio de maior empenho industrial, sentem necessidade de controlar a marcha da evolução e juntar em um 'fascio'(feixe) as energias do país, a fim de alcançar resultados mais eficazes, com menor dispêndio de meios e poder competir com os mais poderosos organismos produtivos estrangeiros. (...) De resto, o corporativismo, tal como tem sido posto em prática nos países em vias de desenvolvimento, apresenta características não diversas das do Corporativismo dirigista de modelo fascista; basta, aliás, pensar que o ordenamento corporativista brasileiro do Estado Novo de Vargas se inspirava diretamente na Carta do Trabalho fascista". (BOBBIO, ibidem, p. 291. Grifo nosso).

10 Decretos de números 19.890 de 18 de Abril de 1931, que dispõe sobre a organização do ensino secundário e 21.241 de 14 de Abril de 1932, que consolida tais disposições.

11 O decreto $\mathrm{n}^{\circ} 19.851$ de 11 de abril de 1931, que instituiu o regime universitário no Brasil - e se constituiu no Estatuto das Universidades Brasileiras - em seu artigo $5^{\circ}$, ao estipular a obrigatoriedade de pelo menos três cursos dentre os cursos de Direito, Medicina, Engenharia e Educação, Ciências e Letras, para a constituição de uma Universidade, consagrava a falta de diversificação em nosso ensino superior, ao mesmo tempo que reforçava a, ainda remanescente, concepção aristocrática de ensino, ao obrigar as Universidades a se voltarem para os cursos formadores de profissionais para as carreiras liberais. (ROMANELLI, 1998, p. 134).

12 Decreto-lei $\mathrm{n}^{\circ} 1.238$ de 2 de Maio de 1939

13 Decreto-lei no 6.029 de 26 de Julho de 1940. 
14 Para uma discussão mais aprofundada a cerca da criação do SENAI, da sua articulação com o conjunto das "Leis" Orgânicas do Ensino e sobre o pensamento pedagógico da burguesia industrial nesse período, ver RODRIGUES, 1998b, especialmente o capítulo um: O Moderno Príncipe Industrial; rumo à história da CNI.

15 CUNHA (op. cit., p. 454) faz alusão ao fato de que Vargas teria "induzido" os industriais a assumirem os custos desse sistema, ameaçando-os de entregar seu controle aos sindicatos de operários.

16 Decretos-lei nos:

4.048 de 22/01/42 - Cria o SENAI;

4.073 de 30/01/42 - "Lei” Orgânica do Ensino Industrial;

4.244 de 09/04/42 - "Lei" Orgânica do Ensino Secundário;

6.141 de 28/12/43 - "Lei” Orgânica do Ensino Comercial;

Depois da queda de Vargas, durante o Governo Provisório de José Linhares e, estando a frente do Ministério da Educação Raul Leitão da Cunha, foram baixados os seguintes Decretos-lei:

8.529 de 02/01/46 - "Lei” Orgânica do Ensino Primário;

8.530 de 02/01/46 - "Lei” Orgânica do Ensino Normal;

8.621 e 8.622 de 10/01/46 - Criam o Serviço Nacional de Aprendizagem Comercial e

9.613 de 20/08/46 - "Lei” Orgânica do Ensino Agrícola.

17 O termo lei aparece entre aspas, por uma referência direta ao fato de que estas "leis" orgânicas, embora sejam assim conhecidas, na verdade, foram Decretos-lei elaborados por uma comissão de "notáveis" presidida por Gustavo Capanema e "baixados" por Getúlio Vargas durante o Estado Novo e por José Linhares durante o Governo Provisório. É a forma que CUNHA (1983) usa para denunciar esse fato.

Recebido 10/06/2010

Avaliado 14/06/2010 